\title{
RELATIONSHIP BETWEEN COGNITIVE DISTORTIONS AND DECISION- MAKING SKILLS AMONG AL-QUDS UNIVERSITY STUDENTS
}

\author{
Omar Rimawi ${ }^{*}$, Hussein ALMasri ${ }^{2}$
}

${ }^{1 *}$ Department of Psychology, Faculty of Education, Al-Quds University, P.O. Box 51000,

Jerusalem, Palestine; ${ }^{2}$ Medical Imaging Department, Al-Quds University, P.O. Box 51000, Jerusalem, Palestine. Email: ${ }^{1 *}$ orimawi@ staff.alquds.edu, ${ }^{2}$ halmasri81@ @staff.alquds.edu

Article History: Received on $24^{\text {th }}$ July 2020, Revised on $20^{\text {th }}$ December 2020, Published on $28^{\text {th }}$ January 2021

\section{Abstract}

Purpose of the study: The purpose of this research is to identify the relationship between cognitive distortions and decision-making skills among Al-Quds University students.

Methodology: The current research was performed on a sample of (264) male and female students chosen using the random method. Both of cognitive distortions and decision-making skills measurements have been used. Validity and reliability of the study instruments were tested, and it was clear that the instruments were sufficiently reliable (stable) enough to meet the objectives of the study.

Main Findings: Findings showed a negative relationship between cognitive distortions and decision-making skills among Al-Quds University students, and also suggested that the means for the total score of cognitive distortions and decision-making skills were moderate. Over-thinking reflected the dominant domain of cognitive distortions. Findings also revealed differences in cognitive distortions in favor of females, Faculty of Humanities, and residents of the village.

Applications of the study: The strength of the negative relationship between distortions and decision-making can be deduced, as there is a need to improve students' understanding of the risks of cognitive distortions, and seek to enhance the ability of decision-making skills.

Novelty: Decision-making is one of the cognitive processes resulted from multiple-choice. Cognitive distortions influence decision-making skills. Thus, the purpose of this study was to overcome the barriers to negative thinking and to improve student capacity for appropriate and effective decision-making skills. We can obtain this using a direct relationship between cognitive distortions and decision-making skills.

Keywords: Cognitive Distortions, Decision-making Skills, Al-Quds University Students, Palestine.

\section{INTRODUCTION}

Cognitive processes have a vital role to play in human thought and their comprehension of various circumstances. Cognitive distortions are some kind of psychological factors that may have a negative impact on student behaviors as they can arise in their way of thinking, comprehension, and decision-making (Li \& Wang, 2013). Beck \& Alford (2009) emphasized that the issue of cognitive distortions is largely due to the fact that the individual distorts facts and evidencebased on false premises and assumptions arising from faulty learning that occurred at one stage in the individual's cognitive development (Sultan, 2018).

Decision-making skills are very important, where the researchers concentrate on how to make decisions about unpredictable events and contradictory situations, in addition to the possibility to recognize the logic of individual decisions (Nagib, 2002). Decisions of this type vary from simple to complicated, depending on the nature and complexity of the situation and the number of challenges it entails, Decision-making is the most challenging task that a person may face in his or her lifetime. It reflects a process that is defined as the perceived option between two or more alternatives (Hantoul, 2013).

These university students bear the burden of making decisions that can help them succeed and cope with university life or take wrong decisions that lead to academic failure (Al-Shraideh, et al., 2010, Simic, et, al., 2017). Decision-making is a mental process that aims at selecting the best available options that are accessible to the individuals in terms of the specific situation that may be linked to work or relationships with others to achieve the desired objectives (Hammond, et al., 2015). It is also an essential part of the individual's personal and professional life so that this process should not be subjected to a factor of coincidence or separated from the reality of its implementation.

Also, risky decisions mean that "the outcome of choosing an option cannot be guaranteed. Consequently, the individual faces the risks of this outcome (Mora, et al., 2018).

And because people have limitations like information processors, biases can, and often do, reduce the amount of thinking and processing a person makes to make a choice, especially in stressful or time-limited situations. The way information is presented and the way analyzes are performed also affect the amount of cognitive resources and the collection of information a person needs in a situation. (Power, 2016) research has shown that there is a human tendency to emphasize the importance of recent experience in estimating future events (Chatfield, 2016). The individual's interpretations of events appear automatically and without a clear will of him, and these distorted automatic thoughts appear sequentially and take the form of beliefs that include dysfunction. (Al-Aajam, 2018) 
Therefore, cognitive distortions are considered negative thoughts that negatively affect the individual's ability to face life events, and then his ability to adapt, which leads to excessive emotional reactions that are not compatible with the situation or event (Al-Shukry, 2018).

(Beck) emphasized that the problem of cognitive distortions lies mainly in the fact that the individual distorts reality and facts based on false premises and false assumptions that the about a wrong learning that occurred in one of the stages of the individual's cognitive development, that is, that the cognitive content of the individual in the state of disorder involves permanent distortion of events, Therefore, many mental disorders and a lack of psychological and social compatibility is largely due to cognitive distortions that affect thinking, perceptions and emotions, causing illogical thinking styles and a negative view of the self, the world and the future (Sultan, 2018).

Al-Khuzai, Walibawi,(2016) indicated that cognitive distortion hinders the student in his awareness and then the correct judgment and appropriate decision, so the student, in this case, carries negative prejudices about the situation, and buried negative impulses and information that is not governed by logic.

Many studies such as (Ersoy, et al., 2019) and (Fan, 2016) indicate the importance of teaching learners the skill of decision-making, and the process of improving decision-making among learners has a positive impact on improving their academic achievement and developing their higher thinking skills. (Phillips-Wren, et al, 2019) also indicated that reducing cognitive biases, supporting learning styles, and managing risky situations increases the process of improving decision-making.

\section{LITERATURE REVIEW}

Previous related studies, such as (Ciccarelli, et al., 2017) and (Aithal, \& Kumar, 2017), suggested that there was a negative correlation between cognitive distortions and decision-making skills. Danner and his colleagues (Danner, et al., 2011) reported a relationship between intelligence and decision-making skills. Also, Sadouq\&Daif (2018) have shown that different thinking approaches have an impact on the decision-making process. The sample consisted of 186 male and female students, the results showed that the various styles of thinking influence the decision-making process.

The findings of a study conducted by Zaghair and Mohamad (2019), the study was conducted on a sample consisted of 400 male and female students from Alyarmouk University showed differences in decision-making skills in favor of females due to gender variable, as well as differences attributed to major variable in favor of the scientific one. Saleh and Jihad (2019) showed a high level of cognitive distortions among adolescents, their study performed on a sample of 450 students; it also revealed differences in favor of males, Tammouni $(\underline{2019})$ conducted a study to investigate the efficiency of a cognitive indicative program in reducing cognitive distortions among Al-Quds Open University students, the sample of his study consisted of 40 students divided into two groups, control and experimental. The findings showed statistically significant differences between the control and experimental groups in the post-assessment on at the measurement of cognitive distortions in favor of the experimental group, Shandoukh and Mizal (2019) found in their study which was conducted on 140 middle school students that cognitive distortions rates were below average. In addition, in their study, Abbarah, et al. (2018) found that cognitive distortions rates were generally high and that there were no differences due to gender, but they revealed differences due to major in favor of literary stream students, the sample of their study included 389 male and female students in the governmental high schools.

Mulhem(2014) in his study "Cognitive Intelligence and its Relationship to Decision-making among Damascus University Students," has demonstrated that there were no differences in the measurement of decision-making skills due to the academic major or place of residence, he conducted his study on a sample consisted of 340 male and female students from different faculties in the university. Also, Al-Subai (2011), in his study "Thinking Styles and its Relationship to Decision-making”, reported that there were no statistically significant differences in thinking approach and decision-making skills due to the major or academic level, the study was performed on 109 employees in the governmental schools. Al-Mansour (2015) study, titled "Intelligence and its Relationship to Decision-making Skills among Damascus University Students," indicated that there were differences in the measurement of decision-making skills due to the major variable in favor of scientific majors, although no differences were found due to the gender variable, but the study revealed differences due to the age in favor of older individuals. A study by Bullock et al. (2014) aimed to identify the differences between decision-maker and decision-reluctant, it was conducted on 223 male and female university students, 83 of them were reluctant and 143 were decision-makers. The study suggested that it is possible to predict low self-efficiency, high negative thinking, and increased obstacles in the decision-making process among those who hesitate to make decisions compared to their peers who can make decisions, Al-Khuzai (2009) conducted a study titled "The Impact of Using Thinking Maps on Increasing Achievement and Developing Decisionmaking among Students of the Faculty of Education," he performed his study on 70 students who were divided into two groups, control and experimental, the findings showed statistically significant differences in decision-making skills amongst university students due to gender in favor of males.

Following the previous research, the goals of the studies were to tackle different variables, including the research on cognitive distortions and decision-making skills with various variables, such as decision-making, thought styles, selfawareness, inductive thinking style, personality disorders, decision-makers, and hesitant ones, and thinking maps. Most 
of the studies used samples ranged from (30-450), the majority of which were from university students; the results of these studies were consistent in some respects but inconsistent in others.

\section{RATIONALE OF THE STUDY}

About the lack of research on the relationship between cognitive distortions and decision-making skills among university students, the current study aimed at investigating this relationship in terms of these variables. While cognitive distortions play a prominent role in cognitive theory, there is a lack of research that examined the relationship between cognitive distortions and decision-making skills. Cognitive distortions impair the individual's ability to cope with life events and hence his ability to make acceptable decisions. Thus, the importance of this study stems from the importance of overcoming the obstacles that impede the decision-making process, as well as the importance of implementing scientific methods and approaches that ensure making rational and purposeful decisions that result in increased productivity and development, solutions to problems, and the development of their higher thinking skills.

\section{Objective}

To identify the relationship between cognitive distortions and decision-making skills among Al-Quds University students.

\section{Hypothesis}

There will be a close relationship between these variables: cognitive distortions and decision-making.

\section{METHODOLOGY}

\section{Study approach}

The researcher used the relational descriptive approach to achieve the objectives of the current study. This approach is defined as an approach that investigates an established phenomenon, event, or problem from which information can be obtained to answer research questions or hypotheses.

\section{Study population and sample}

The population of this study consisted of all regular first-term students at Al-Quds University, who aged from 18 to 22 years and do not have any mental or healthy problems, in the academic year 2019. They were (5000) male and female students according to the Department of Registration and Admission. The study sample included 264 male and female students with a ratio of $5 \%$ who were selected using the random method. Table (1) shows the demographic distribution of the participants by the variables of the study.

Table 1: Demographic distribution of the participants by the variables of the study

\begin{tabular}{llll}
\hline Variable & Level & n & Percentage (\%) \\
\hline \multirow{3}{*}{ Gender } & Male & 126 & 47.7 \\
\cline { 2 - 4 } Faculty & Female & 138 & 52.3 \\
\hline \multirow{3}{*}{ Academic level } & Science & 153 & 58.0 \\
\cline { 2 - 4 } & Humanities & 111 & 42.0 \\
& $1^{\text {st }}$ year & 47 & 17.8 \\
\cline { 2 - 4 } & $2^{\text {nd }}$ year & 63 & 23.9 \\
\cline { 2 - 4 } & $3^{\text {rd }}$ year & 62 & 23.5 \\
\cline { 2 - 4 } & $4^{\text {th }}$ year and above & 92 & 34.8 \\
\hline \multirow{2}{*}{ Place of residence } & Village & 117 & 44.3 \\
\cline { 2 - 4 } & City & 130 & 6.4 \\
\cline { 2 - 4 } & Camp & 17 & 6.2 \\
\hline
\end{tabular}

\section{Instrumentation}

Based on the review of the educational literature, previous research, and the instruments used in the current study, the measurement of cognitive distortions developed by Salha (2018) was used because it was appropriate for the purpose of the study, this measurement was also used in Aladily, \&Alquraishi (2016). The measurement consisted of 38 statements (Appendix A) divided into six fields represent cognitive distortions. The current study also used the decision-making measurement developed by Ghareeb\&Ayash (2018) and used in Al-Mansour (2015), it consisted of 23 statements. The participants' responses were formulated as five-point Likert scale statements, where the participants' responses to the statements and the correction method were as follows: very extremely ( 5 scores), extremely (4 scores), moderately ( 3 scores), slightly (2 scores), very slightly (1 score). 
Table 2: Fields of cognitive distortions measurement

\begin{tabular}{clr}
\hline No. & \multicolumn{1}{c}{ Fields of cognitive distortions measurement } & $\begin{array}{l}\text { Number } \\
\text { of items }\end{array}$ \\
\hline 1 & $\begin{array}{l}\text { All-or-Nothing thinking (binary thinking): it is a huge extremist of } \\
\text { judgment, as some people express it with (white or black). }\end{array}$ & 5 \\
\hline 2 & $\begin{array}{l}\text { Excessive generalization (over-generalization): in this cognitive } \\
\text { distortion, we may come across a general conclusion based on an event } \\
\text { or evidence. If something happens for only one time, we may predict } \\
\text { that it will happen again. }\end{array}$ & 6 \\
\hline 3 & $\begin{array}{l}\text { Assessment errors: this means that an individual exaggerates the value } \\
\text { of his problems and faults or decreases and humiliates his traits. }\end{array}$ & 7 \\
\hline 4 & $\begin{array}{l}\text { Optimal thinking (over-thinking): the individual obligates himself to be } \\
\text { highly qualified and competitive, and to accomplish as much important } \\
\text { and valuable things as possible without making any mistakes. }\end{array}$ & 6 \\
\hline 5 & $\begin{array}{l}\text { Incorrect inference (arbitrary): a logical error bases on unlimited } \\
\text { evidence from previous experiences, it allows the individual to make a } \\
\text { final decision about the future. }\end{array}$ & 7 \\
\hline 6 & $\begin{array}{l}\text { Self-blame: the person feels like he triggers the adverse events that } \\
\text { occur around him, but he is not really responsible for that. }\end{array}$ & 7 \\
\hline Total & &
\end{tabular}

The statistical criterion was set out, using the following equation:

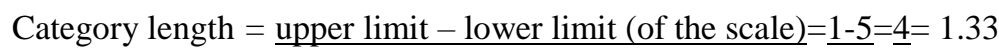

Number of presumed categories33

The following scores were adopted to determine the levels of the means of the participants' responses; the three levels were as follows:

- $1+1.33=2.33$, thus, the statements with a mean range between $(1 \geq \mathrm{m} \leq 2.33)$ indicate a low level.

- $2.34+1.33=3.67$, thus, the statements with a mean range between $(2.34 \geq \mathrm{m} \leq 3.67)$ indicate a moderate level.

- $3.38+1.33=5$, thus, the statements with a mean range between $(3.68 \geq \mathrm{m} \leq 5)$ indicate a high level.

\section{Instrument validity}

The instrument validity scores were derived as it was tested by a group of specialists in the fields of psychology, measurement, and assessment. The Person Correlation coefficient was also measured as it was extremely suitable for the current study.

\section{Instrument reliability}

The reliability of the instrument was checked by measuring the total score of the reliability coefficient for the fields of the study according to the "Cronbach's Alpha" equation, the total score for cognitive distortions among the students of Al-Quds University was (0.92) while the total score for decision-making was (0.75), which indicated that the study instrument was sufficiently reliable (stable) to meet the study purposes.

\section{Statistical treatment}

After collecting data and testing its validity, it was coded (given certain digits) as a prelude to insert it into the computer for proper statistical treatment and to analyze data according to the study's questions. Statistical treatment of the data was carried out by the extraction of the means and standard deviations for each statement in the questionnaire, as well as the results of the t-test, One-Way ANOVA test, Person Correlation coefficient, and reliability equation (Cronbach Alpha) were measured using (23-SPSS) program.

\section{Results}

The findings of this study showed a negative relationship between cognitive distortions and decision-making skills among Al-Quds University students and also suggested that the mean of the total score for cognitive distortions and decision-making skills was moderate. 
Table3: Pearson Correlation Coefficient between cognitive distortions and decision-making skills

\begin{tabular}{|c|c|c|c|}
\hline \multirow{3}{*}{ Cognitive Distortions/decision-making skills } & Pearson Correlation & 1 & $-.343^{* *}$ \\
\hline & Sig. (2-tailed) & & .000 \\
\hline & $\mathrm{N}$ & 264 & 264 \\
\hline
\end{tabular}

\section{** Correlation is significant at the 0.01 level (2-tailed)}

Table (3) shows that the value of Pearson Correlation Coefficient between cognitive distortions and decision-making skills as $\left(R=-0.343^{* *}\right)$ at significance level $(P=-0.00)$, that is, there was a statistically significant negative relationship, in other words, the higher the level of cognitive distortions, the lower the level of decision-making, and vice versa.

Table 4: Results of the statistical analysis of means and standard deviations of the participants' responses to cognitive distortions and decision-making skills measurements among students at Al-Quds University

\begin{tabular}{llll}
\hline Field & $\mathrm{N}$ & Mean & SD \\
\hline All-or-Nothing thinking (binary thinking) & 264 & 3.53 & .60 \\
\hline Excessive generalization(over-generalization) & 264 & 3.35 & .65 \\
\hline Assessment errors & 264 & 3.44 & .58 \\
\hline Optimal thinking (over-thinking) & 264 & 3.79 & .57 \\
\hline Incorrect inference (arbitrary) & 264 & 3.43 & .62 \\
\hline Self-blame & 264 & 3.52 & .66 \\
\hline The total score for cognitive distortions & 264 & 3.48 & .53 \\
\hline The total score for decision-making & 264 & 3.49 & .41 \\
\hline
\end{tabular}

Table (4) shows that the mean and the standard deviation of the total score of the cognitive distortions were moderate $(\mathrm{SD}=0.53 ; \mathrm{M}=3.48$ ). The highest mean was by the field of optimal thinking (over-thinking), and the lowest one was for excessive generalization (over-generalization). The mean and standard deviation of the total score of decisionmaking skills were $(\mathrm{SD}=0.41 ; \mathrm{M}=3.49)$. Thus, they were moderate.

Table 5: Results of the statistical analysis of the(t-test) for the participants' responses to the cognitive distortions among Al-Quds University students based on gender and faculty variables

\begin{tabular}{|c|c|c|c|c|c|c|}
\hline Field & Variable & $\mathrm{N}$ & Mean & $\mathrm{SD}$ & $t$-value & $P$-value \\
\hline \multirow[b]{2}{*}{ Cognitive distortions/ gender } & Male & 126 & 3.37 & .52 & \multirow{2}{*}{-3.28} & \multirow{2}{*}{.00} \\
\hline & Female & 138 & 3.58 & .52 & & \\
\hline \multirow[b]{2}{*}{$\begin{array}{l}\text { Cognitive distortions/ } \\
\text { faculty }\end{array}$} & Science & 153 & 3.42 & .57 & \multirow[b]{2}{*}{-2.17} & \multirow[b]{2}{*}{.03} \\
\hline & Humanities & 111 & 3.56 & .47 & & \\
\hline \multirow[b]{2}{*}{$\begin{array}{l}\text { Decision-making skills/ } \\
\text { gender }\end{array}$} & Male & 126 & 3.68 & .42 & \multirow[b]{2}{*}{7.58} & \multirow[b]{2}{*}{.00} \\
\hline & Female & 138 & 3.33 & .32 & & \\
\hline \multirow[b]{2}{*}{$\begin{array}{l}\text { Decision-making } \\
\text { skills/faculty }\end{array}$} & Science & 153 & 3.54 & .46 & \multirow[b]{2}{*}{2.03} & \multirow[b]{2}{*}{.04} \\
\hline & Humanities & 111 & 3.44 & .31 & & \\
\hline
\end{tabular}

Table (5) shows the results of (t-test) and the means of cognitive distortions due to the gender variable. The results revealed statistically significant differences among females as the highest mean and standard deviation were $(\mathrm{SD}=0.52$; $\mathrm{M}=3.58)$ compared to males $(\mathrm{SD}=0.52 ; \mathrm{M}=3.37)$, the values of $(\mathrm{t})$ and $(\mathrm{p})$ were $(\mathrm{t}=-3.28 ; \mathrm{p}=0.00)$ which means that the differences were in favor of females. The results also showed statistically significant differences in the cognitive distortions due to the faculty variable, where the standard deviation and the highest mean of Faculty of Humanities were $(\mathrm{SD}=0.47 ; \mathrm{M}=3.56)$ compared to the Faculty of Science $(\mathrm{SD}=0.57 ; \mathrm{M}=3.42)$. The values of $(\mathrm{t})$ and $(\mathrm{p})$ were $(\mathrm{t}=-$ 2.17; $\mathrm{p}=0.03$ ), and the differences were in favor of the Faculty of Humanities.

The results of (t-test) and the means of decision-making skills also show that there were statistical differences among males due to the gender variable as the highest mean and standard deviation were ( $\mathrm{SD}=0.42 ; \mathrm{M}=3.68$ ) compared to females $(S D=0.32 ; M=3.33)$. The values of $(T)$ and $(P)$ were $(t=7.58 ; p=0.00)$. Thus, the differences were in favor of males. The results of the (t-test) for decision-making skills revealed statically significant differences because the highest mean and standard deviation for the Faculty of Science were $(\mathrm{SD}=0.46 ; \mathrm{M}=3.54)$ compared to the Faculty of Humanities $(\mathrm{SD}=0.31 ; \mathrm{M}=3.44)$. The values of $(\mathrm{T})$ and $(\mathrm{p})$ were $(\mathrm{T}=2.03 ; \mathrm{P}=0.04)$, that is, the differences were in favor of the Faculty of Humanities. 
Table 6: Results of the statistical analysis of (One Way Anova) for the participants' responses to cognitive distortions among Al-Quds University students due to gender and faculty variables.

\begin{tabular}{|c|c|c|c|c|c|c|}
\hline Field & Level & $\mathrm{N}$ & Mean & SD & $F$-value & $P$-value \\
\hline \multirow{4}{*}{$\begin{array}{l}\text { Cognitive distortions/ } \\
\text { academic level }\end{array}$} & $1^{\text {st }}$ year & 47 & 3.69 & .52 & \multirow{4}{*}{6.41} & \multirow{4}{*}{.000} \\
\hline & $2^{\text {nd }}$ year & 63 & 3.60 & .44 & & \\
\hline & $3^{\text {rd }}$ year & 62 & 3.40 & .54 & & \\
\hline & $\begin{array}{l}4^{\text {th }} \text { year and } \\
\text { above }\end{array}$ & 92 & 3.34 & .55 & & \\
\hline \multirow{3}{*}{$\begin{array}{l}\text { Cognitive distortions/ } \\
\text { place of residence }\end{array}$} & Village & 117 & 3.60 & .50 & \multirow{3}{*}{5.68} & \multirow{3}{*}{.004} \\
\hline & City & 130 & 3.40 & .56 & & \\
\hline & Camp & 17 & 3.28 & .35 & & \\
\hline
\end{tabular}

Table (6) shows the results of the One Way Anova test for the cognitive distortions due to the academic level. The highest mean and standard deviation were $(\mathrm{SD}=0.52, \mathrm{M}=369)$ in favor of first-year students compared to the higher years, the value of $(F)$ is $(F=6.41 ; 0.00)$, that is, there were differences due to the academic level variable in favor of the first year. There were also differences attributable to the pace of residence in favor of villagers where $(\mathrm{SD}=0.50 ; \mathrm{M}=$ 3.60), the values of $(\mathrm{F})$ and $(\mathrm{P})$ were $(\mathrm{F}=5.68 ; \mathrm{P}=0.00)$.

Table 7: Results of the statistical analysis of (One Way Anova) for the participants' responses to decision-making skills among Al-Quds University students due to gender and faculty variables.

\begin{tabular}{|c|c|c|c|c|c|c|}
\hline Field & Level & $\mathrm{N}$ & Mean & SD & $F$ value & $P$ value \\
\hline \multirow{4}{*}{$\begin{array}{c}\text { Decision- } \\
\text { making/academic } \\
\text { level }\end{array}$} & $1^{\text {st }}$ year & 47 & 47 & 3.37 & .27 & \multirow[t]{4}{*}{.000} \\
\hline & $2^{\text {nd }}$ year & 63 & 63 & 3.29 & .35 & \\
\hline & $3^{\text {rd }}$ year & 62 & 62 & 3.57 & .39 & \\
\hline & $\begin{array}{l}4^{\text {th }} \text { year } \\
\text { and } \\
\text { above }\end{array}$ & 92 & 92 & 3.65 & .44 & \\
\hline \multirow{3}{*}{$\begin{array}{l}\text { Decision- } \\
\text { making/place of } \\
\text { residence }\end{array}$} & Village & 117 & 117 & 3.30 & .33 & \multirow{3}{*}{.000} \\
\hline & City & 130 & 130 & 3.67 & .42 & \\
\hline & Camp & 17 & 17 & 3.65 & .18 & \\
\hline
\end{tabular}

Table 7 shows that the results of One Way Anovatestfor decision-making skills based on the academic level revealed differences in favor of fourth-year students and above ( $\mathrm{SD}=0.44 ; \mathrm{M}=3.65$ ) compared to the lower years as the values of $(\mathrm{F})$ and $(\mathrm{P})$ were $(\mathrm{F}=12.67 ; \mathrm{P}=0.00)$. There were also differences due to the place of residence in favor of the city residents, the mean and the standard deviation were $(\mathrm{SD}=0.42 ; \mathrm{M}=3.67)$ and $(\mathrm{F}=29.73 ; \mathrm{P}=0.00)$.

\section{DISCUSSION}

The results obtained through this study demonstrated a statistically significant negative relationship between cognitive distortions and decision-making skills. The higher the cognitive distortions, the lower would be the level of decisionmaking skills, and vice versa. This finding is consistent with the following studies: (Ciccarelli, et al., 2017; Aithal, \& Kumar, 2017; Al-Mansour, 2015, \& Danner, et al., 2011). The findings from this study also showed that the mean of the total score for cognitive distortions was moderate, this result is inconsistent with the research of Saleh and Jiad (2019) and Abbarah, et al. (2018), suggesting an increase in cognitive distortions of the samples used in this study. The findings from Tammouni (2019) and Shandoukh and Mizal (2019) showed a low rate of cognitive distortions. The highest mean was for the field of optimal thinking (over-thinking) followed by the field of all-or-nothing thinking (binary thinking), while the lowest one was for the field of excessive generalization (over-generalization). Thus, the mean for the total score of decision-making skills was moderate.

The results also showed statistically significant differences due to the study variables, as they also revealed differences in cognitive distortions among students of Al-Quds University for the gender variable in favor of females, and this result is inconsistent with Saleh, and Jiyad (2019) as well as Abbarah et al (2018). We can explain this result by the nature of stressful environmental conditions as well as the extent of the socialization that females receive compared to males, the results also revealed differences attributed to the Faculty of Humanities compared to the Faculty of Science, and this is consistent with the study of Abbarah et al.(2018). These differences were the result of different educational approaches used to teach literary and scientific subjects, where logic is used in teaching scientific subjects more than in literary approaches. Teaching methods influence student thinking, just as the students of the scientific stream follow the scientific methods more than the students of the literary stream do. The findings revealed differences in the academic level in favor of first-year students compared to the students in higher years. The academic level of first-year students was low compared to the academic level of the students in higher years; this can be modified during the academic years. When the students advance at their academic level, they have fewer opportunities to expose themselves to cognitive distortions. There have also been differences between the residents of the village and the residents of the city, resulting 
from socialization, where some parents have some myths and irrational thoughts in mind. As a result, children have the same thoughts and values.

The findings of the current study showed differences in decision-making skills amongst of Al-Quds University students due to gender in favor of males. This finding is consistent with Al-Khuzai (2009) and is inconsistent neither with Zaghair, and Mohamad (2019) or Al-Mansour (2015). This result is thought to have a rational outcome because students at higher academic levels have the capacities and abilities to make decisions compared to their peers at fewer levels. The study found differences due to the place of residence in favor of the residents of the city. This finding is inconsistent with Mulhem (2014). Socialization has an impact on the nature of life in the city because life events in the city are more active than those in the village. This requires training children on decision-making in early childhood. The autonomy of the residents of the city is greater than that of the village residents, where the dependence of the children in the village is greater than that of those who are in the city.

\section{CONCLUSIONS}

Based on the findings of the current study, it is clear that students at Al-Quds University have a moderate degree of cognitive distortions, and the highest level of cognitive distortion field is optimal thinking (over-thinking), whereas the lowest mean is for the field of excessive generalization (over-generalization). The findings also showed that there is a negative relationship between cognitive distortions and decision-making among Al-Quds University students because all the variables were reversed. It was found that the high mean of distortions was low in decision-making, and vice versa. As a result, the variables (females, human college, first-year students, and residents of the village) were high in cognitive distortions, while the variables were low in decision-making which means there were differences between students, in addition to differences between all study variables.

\section{RECOMMENDATION}

Based on the findings of the study, the following is recommended:

- Dedicating most of the teachers' attention to logical thinking programs in teaching students.

- Raising awareness among students of the dangers of cognitive distortions.

- Using cognitive distortions as an important predictor to test decision-making skills.

\section{LIMITATION AND STUDY FORWARD}

This study focused mainly on cognitive distortions and decision-making skills among Al-Quds University students. It is suggested that future researchers stretch out this research to other universities across Palestine, or conduct a comparative analysis between several universities.

\section{ACKNOWLEDGEMENTS}

The authors would like to thank Al-Quds university students for their participation in filling out the questionnaire.

\section{AUTHORS CONTRIBUTION}

The first author contributed to the process of studying the entire data, literature review, categorizing data, validity checks, and data interpretation, and checking of the data analysis process. The second author contributed to the preparation of research plans, research problems, data collection, and evaluating the data analysis process, and interpretation of results.

\section{CONFLICT OF INTERESTS}

The authors declare that they have no conflicting interests.

\section{REFERENCES}

1. Abbarah, H., Rahhal, M., Hajj M. (2018). Cognitive Distortions and their Relationship to the Appearance of Symptoms of Obsessive-Compulsive Personality Disorder in Adolescents. Jordanian Journal of Educational Sciences, 14 (4), 411-427.

2. Aithal, P., \& Kumar, P. (2017). Ideal analysis for decision making in critical situations through six thinking hats method. International Journal of Applied Engineering and Management Letters (IJAEML), 1(2), 1-9.

3. Al-AajamN. (2018). Educational Counselors EgoResiliencyand Its Relation with Cognitive Distortion Among Preparatory Stage Students, Al-Fatih journal, 14 (75), 260-281.

4. Aladily, R., \&Alquraishi, K.(2016). Cognitive Distortions among Middle School Students, Cognitive Distortions of Middle School Students, Journal of the Faculty of Basic Education, 22 (95), 585-612.

5. Al-Khuzai, A. (2009). The Ability of Decision-making according to the Efficiency of the Cognitive representation of Information among University Students.Al-Qadisiyah Journal for Humanities, 12 (4), 291318. 
6. Al-Khuzai, A., \&Walibawi, Kh. (2016). Anxiety of cognitive perception on the perceived self-functioning of university students. Journal of Al-qadisiya in arts and educational sciences, 15 (1), 299-299.

7. Al-Mansour, Z. (2015). Intelligence and its Relationship to Decision-making Skill. A Field Study on a Sample of Damascus University Students, unpublished Master Thesis, University of Damascus. Faculty of Education. Syria. Damascus.

8. Al-Shraideh, M., Bechara, M., \& Abu Darwish, M. (2010). The Ability of the First-year Students at AlHussein Bin Talal University to Make Decisions. Journal of the Faculty of Education, 34 (3), 465-439.

9. Al-Shukry, I. (2018). Hoarding disorder and its relationship to cognitive distortions. unpublished master's thesis, University of Baghdad, College of Arts, Iraq.

10. Al-Subai, A. (2011). Methods of Thinking and their Relationship to Decision-making among a Sample of Female Directors from Government Departments in the Jeddah Governorate, Unpublished Master Thesis, College of Education, Umm Al-Qura University, Saudi Arabia.

11. Beck, A., \& Alford, B. (2009). Depression: Causes and treatment. University of Pennsylvania Press.

12. Bullock-Yowell, E., McConnell, A., \&Schedin, E. (2014). Decided and undecided students:Career selfefficacy, negative thinking, and decision-making difficulties. Nacada Journal, 34(1), 22-34. https://doi.org/10.12930/NACADA-13-016

13. Chatfield, T. (2016). The trouble with big data: The 'recency bias'. Retrieved from http://www.bbc.com/future/story/20160605-the-trouble-with-big-data-its-called-the-recency-bias.

14. Ciccarelli, M., Griffiths, M., Nigro, G., \& Cosenza, M. (2017). Decision making, cognitive distortions, and emotional distress: a comparison between pathological gamblers and healthy controls. Journal of behavior therapy and experimental psychiatry, 54, 204-210. https://doi.org/10.1016/j.jbtep.2016.08.012

15. Danner, D., Hagemann, D., Schankin, A., Hager, M., \& Funke, J. (2011). Beyond IQ: A latent state-trait analysis of general intelligence, dynamic decision making, and implicit learning. Intelligence, 39(5), 323334.https://doi.org/10.1016/j.intell.2011.06.004

16. Ersoy, E., Ogurlu, U., \& Aydin, H. (2019). Gifted students' and their parents' perceptions of decision-making processes: A Turkish case. Interchange, 50(3), 403-421.https://doi.org/10.1007/s10780-019-09357-1.

17. Fan, J. (2016). The role of thinking styles in career decision-making self-efficacy among university students. Thinking Skills and Creativity, 20, 63-73. https://doi.org/10.1016/j.tsc.2016.03.001

18. Ghareeb, S., Ayyash L., (2018). Decision-making for Graduate Studies Students at Baghdad University, Lark Journal of Philosophy, Linguistics, and Social Sciences, 3 (28), 178-196.

19. Hammond, J., Keeney, R., \&Raiffa, H. (2015). Smart choices: A practical guide to making better decisions. Harvard Business Review Press.

20. Hantoul, A. (2013). Predicting the Ability of Decision-making among a Sample of Educational Counselors in Jizan through the Effectiveness of the Perceived Self, Journal of Education, 155 (2), 173-199.

21. Li, H., \& Wang, S. (2013). The role of cognitive distortion in online game addiction among Chinese $\begin{array}{llll}\text { adolescents. Children } \quad \text { and } & \text { youth services }\end{array}$ https://doi.org/10.1016/j.childyouth.2013.05.021

22. Mora, M., Phillips-Wren, G., \& Wang, F. (2018). The role of decision-making support systems in risk management. In The Routledge companion to risk, crisis and security in business (pp. 441-456). Routledge.

23. Mulhem, S. (2014). Emotional Intelligence and its Relation to Decision-making. Field Study for a Sample of Damascus University Students, Unpublished Master Thesis, Faculty of Educational Sciences, University of Damascus, Syria.

24. Nagib, M. (2002). Cognitive Patterns among Administrative Decision Makers and their Relationship to Some Personality Traits. Journal of Psychological Studies, 12 (1), 63-113.

25. Phillips-Wren, G., Power, D. J., \& Mora, M. (2019). Cognitive bias, decision styles, and risk attitudes in decision making and DSS. https://doi.org/10.1080/12460125.2019.1646509

26. Power, D. J. (2016). Data science: supporting decision-making. Journal of Decision systems, 25(4), 345356.https://doi.org/10.1080/12460125.2016.1171610

27. Sadouq, F., Daif A. (2018). The Role of Strategic Thinking Patterns in Decision-making, a Field Study for the Pay Industry in Jelfa Foundation. Al-Bashaer Economic Magazine, 5 (1) 278-293.

28. Saleh, Z., \&Jiyad M. (2019). Bullying and its Relationship to Cognitive Distortions among Adolescents in Secondary Schools, Faculty of Arts / University of Qadisiyah, Journal of the Faculty of Basic Education for Educational Sciences and Humanities No. (43), 1223-1245.

29. Salha, R. (2018). Cognitive distortions and relationship with morbid personality traits in reform and rehabilitation centers in governorates of the Gaza strip. Unpublished Master Thesis, College of Education, AlAqsa University, Gaza

30. Shandoukh, A., Mizal F., (2019). Cognitive Distortions among Middle School Students. Journal of the Faculty of Education, (36), 323-355.

31. Simic, D., Kovacevic, I., Svircevic, V., \&Simic, S. (2017). 50 years of fuzzy set theory and models for supplier assessment and selection: A literature review. Journal of Applied Logic, 24, 85-96. 
32. Sultan, R. (2018). Possible Self and its Relationship to Cognitive Euphoria among Distinguished Students in Distinguished Secondary Schools, Unpublished Master Thesis, College of Education for Girls, University of Baghdad, Baghdad.

33. Tammouni, A. (2019). Effectiveness of a Counseling Program to Reduce Cognitive Distortions among AlQuds Open University Students, Unpublished Master Thesis, Al-Quds Open University, Palestine.

34. Zaghair, M., Mohamad, M. (2019). Ethical Decision Making and its Relationship with Self-Awareness among University Students, Faculty of Education, Al-Mustansiriya University, Journal of Psychological Research, 30 (4), 664-681.

\section{Appendix A}

Dear students

Greetings,

The researcher is conducting a scientific study titled "Relationship between Cognitive Distortions and Decision-Making Skills among Al-Quds University students".Kindly fill out the questionnaire honestly and objectively, realizing that the information will be kept confidential and will only be used for scientific research purposes.

Please Accept my Best Regards.

Part 1: General information

Please $(\sqrt{ })$ in the brackets next to the answer applies to you.

Gender:() Male() Female

Faculty:() Scientific() Humanities

Academic level:() First year() Second year() Third year() Fourth year and above

Place of residence:() City() Village() Camp

Measurement of Cognitive Distortions

\begin{tabular}{|c|c|c|c|c|c|c|}
\hline 1 & $\begin{array}{l}\text { I refuse half measures (It is all or } \\
\text { nothing) }\end{array}$ & $\begin{array}{l}\text { very } \\
\text { extremely }\end{array}$ & extremely & moderately & Slightly & $\begin{array}{l}\text { very } \\
\text { slightly }\end{array}$ \\
\hline 2 & $\begin{array}{l}\text { In the case where I meet someone } \\
\text { who does not like to dealing with } \\
\text { me, I feel like not everyone likes } \\
\text { me. }\end{array}$ & & & & & \\
\hline 3 & $\begin{array}{l}\text { I seek for achieving goals and } \\
\text { levels that seem difficult to achieve } \\
\text { for others. }\end{array}$ & & & & & \\
\hline 4 & $\begin{array}{l}\text { I keep myself more accountable } \\
\text { than others do to themselves. }\end{array}$ & & & & & \\
\hline 5 & $\begin{array}{l}\text { I consider myself to be responsible } \\
\text { for my grief. }\end{array}$ & & & & & \\
\hline 6 & I feel like I am always right. & & & & & \\
\hline 7 & $\begin{array}{l}\text { When I make a mistake, I do not } \\
\text { consider it a failure as others see it. }\end{array}$ & & & & & \\
\hline 8 & $\begin{array}{l}\text { I see things black or white, I never } \\
\text { see them gray. }\end{array}$ & & & & & \\
\hline 9 & $\begin{array}{l}\text { I conclude things quickly without } \\
\text { looking through the details. }\end{array}$ & & & & & \\
\hline 10 & $\begin{array}{l}\text { I always seek for excellence and } \\
\text { perfection in all that I do. }\end{array}$ & & & & & \\
\hline 11 & $\begin{array}{l}\text { In any situation I encounter, I feel } \\
\text { like I am always right. }\end{array}$ & & & & & \\
\hline 12 & $\begin{array}{l}\text { When I make the least mistakes, I } \\
\text { cruelly hold myself accountable. }\end{array}$ & & & & & \\
\hline 13 & $\begin{array}{l}\text { I am trying to achieve my goals } \\
\text { extremely precisely. }\end{array}$ & & & & & \\
\hline
\end{tabular}




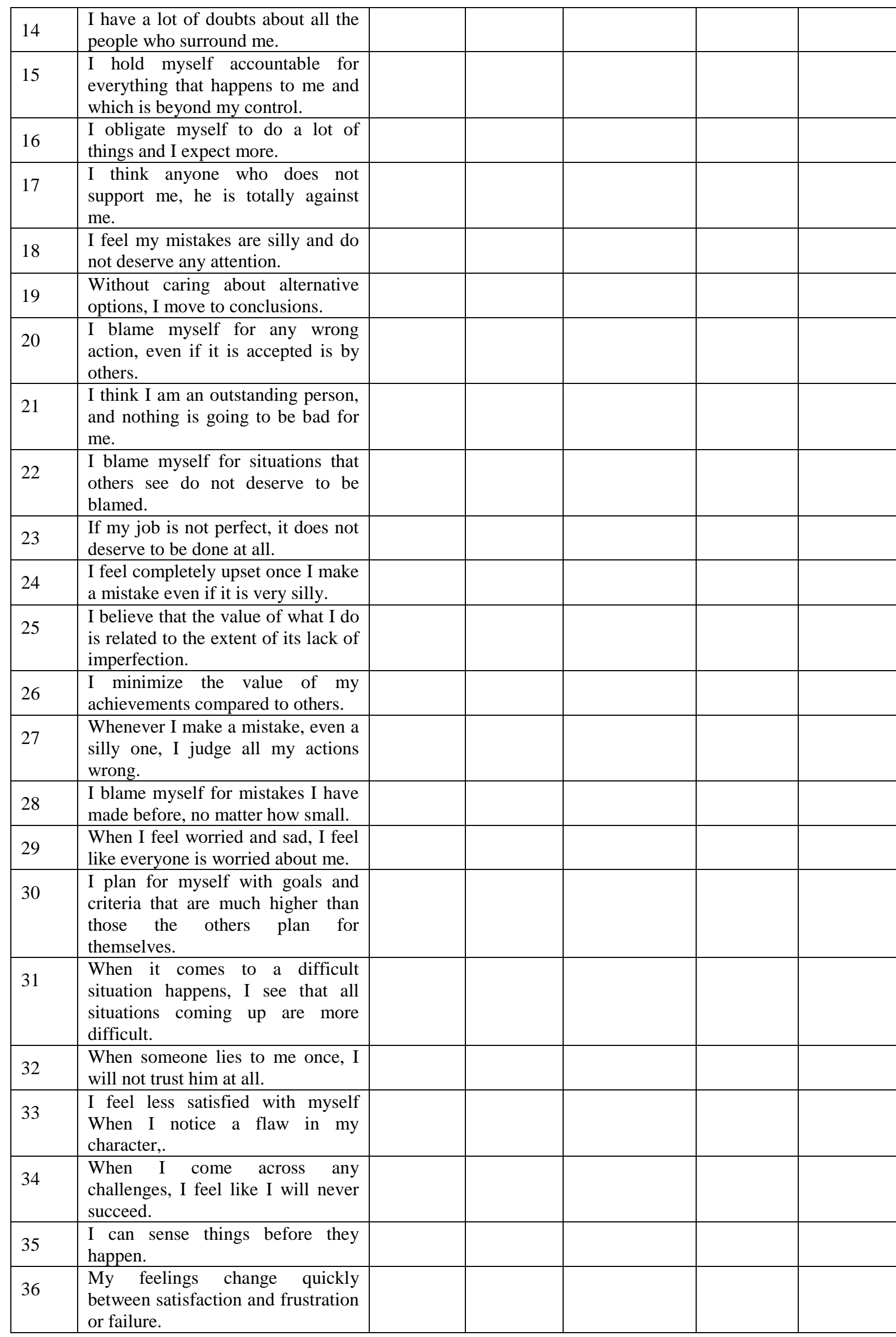




\begin{tabular}{|l|l|l|l|l|l|}
\hline 37 & $\begin{array}{l}\text { I am really upset since I think a lot } \\
\text { about my future. }\end{array}$ & & & & \\
\hline 38 & $\begin{array}{l}\text { It makes me mad to do less than my } \\
\text { expectations. }\end{array}$ & & & & \\
\hline
\end{tabular}

The distribution of items based on Cognitive Distortions Measurement fields.

\begin{tabular}{|l|l|l|l|}
\hline No. & Fields & Number of Items & Distribution of Items \\
\hline 1 & All-or-Nothing thinking (binary thinking) & 5 & $1-8-17-23-36$ \\
\hline 2 & $\begin{array}{l}\text { Excessive generalization } \\
\text { generalization) }\end{array}$ & 6 & $2-27-29-31-32-37$ \\
\hline 3 & Assessment errors & 7 & $7-18-24-26-33-34-38$ \\
\hline 4 & Optimal thinking (over thinking) & 6 & $3-10-13-16-25-30$ \\
\hline 5 & Incorrect inference (arbitrary). & 7 & $6-9-11-14-19-21-35$. \\
\hline 6 & Self-blame. & 7 & $4-5-12-15-20-22-28$. \\
\hline
\end{tabular}

Measurement of Decision-Making Skills

\begin{tabular}{|c|c|c|c|c|c|c|}
\hline No. & Items & $\begin{array}{l}\text { very } \\
\text { extremely }\end{array}$ & extremely & moderately & Slightly & $\begin{array}{l}\text { very } \\
\text { slightly }\end{array}$ \\
\hline 1 & $\begin{array}{l}\text { I can choose the best time for } \\
\text { decision-making. }\end{array}$ & & & & & \\
\hline 2 & $\begin{array}{l}\text { When I make my decisions, I } \\
\text { base on my knowledge of } \\
\text { facts. }\end{array}$ & & & & & \\
\hline 3 & $\begin{array}{l}\text { I make definite and clear } \\
\text { decisions. }\end{array}$ & & & & & \\
\hline 4 & $\begin{array}{l}\text { I understand the of time } \\
\text { importance in decision- } \\
\text { making process. }\end{array}$ & & & & & \\
\hline 5 & $\begin{array}{l}\text { I gather the facts I need } \\
\text { before I make a decision. }\end{array}$ & & & & & \\
\hline 6 & $\begin{array}{l}\text { I verify the consequences of } \\
\text { the decision. }\end{array}$ & & & & & \\
\hline 7 & $\begin{array}{l}\text { I value the responsibility of } \\
\text { decision-making. }\end{array}$ & & & & & \\
\hline 8 & $\begin{array}{l}\text { I am responsible for failure } \\
\text { when I make a wrong } \\
\text { decision. }\end{array}$ & & & & & \\
\hline 9 & $\begin{array}{l}\text { I refer to rules for informing } \\
\text { the decision-making process. }\end{array}$ & & & & & \\
\hline 10 & $\begin{array}{l}\text { I set out the benefits of the } \\
\text { decision. }\end{array}$ & & & & & \\
\hline
\end{tabular}






very extremely (5 scores), extremely (4 scores), moderately (3 scores), slightly (2 scores), very slightly (1 score). 